\title{
TUTURAN PERSUASIF DALAM VIDEO BLOG KECANTIKAN: KAJIAN PRAGMASTILISTIKA
}

\author{
Dwi Novitasari*, Budinuryanta Yohanes, Suhartono \\ Jurusan Pendidikan Bahasa dan Sastra, Fakultas Bahasa dan Sastra, Universitas Negeri Surabaya, Jalan Lidah \\ Wetan Surabaya, Indonesia \\ *Corresponding author: dwinovitasari16070835014@mhs.unesa.id
}

\section{INFORMASI ARTIKEL}

Sejarah Artikel

Diterima: 23/10/2019

Direvisi: 28//11/2019

Diterima: 30/11/2019

Tersedia Daring: 28/12/2019

Kata Kunci

Tuturan persuasif

Video blog

Pragmastilistika

\section{ABSTRAK}

Penelitian ini bertujuan untuk menganalisis bentuk persuasif dalam kumpulan video blog kecantikan. Data dalam penelitian ini adalah tuturan dari tiga naravlog kecantikan dalam satu konteks pembahasan yang sama. Data dianalisis menggunakan metode analisis pragmatik fungsional. Hasil pembahasan dalam penelitian ini menunjukkan adanya konsistensi, otoritas, dan pembuktian dari penutur untuk memersuasi penonton. (1) Bentuk tuturan konsistensi terlihat pada saat penutur menunjukkan keadaan sebenarnya tentang sesuatu. Konsistensi adalah sarana utama memperoleh tujuan bertutur. (2) Bentuk kedua adalah otoritas yakni wewenang penutur membuat aturan. Aturan tersebut dibuat untuk mendapatkan kepatuhan terhadap sasaran persuasi. (3) Bentuk ketiga adalah pembuktian, yakni cara menimbulkan kesan yang dilakukan penutur kepada lawan tutur. Cara tersebut menimbulkan kesan bahwa produk yang ditawarkan banyak peminatnya.

\section{ABSTRACT}

Keywords persuasive speech vlog pragmastylistics
This study aims to analyze the persuasive form in a collection of beauty blog videos. The data in this study were the accounts of three beauty bloggers in the same discussion context. Data were analyzed using functional pragmatic analysis methods. The results of the discussion in this study indicate the consistency, authority, and proof of speakers to persuade the audience. (1) The form of consistency speech is seen when the speaker shows the true state of something. Consistency is the main means of obtaining the spoken goals. (2) The second form is authority, namely the authority of the speaker to make the rules. These rules are made to get compliance with the goals of persuasion. (3) The third form is proof; it is how to give an impression that the speaker speaks to the interlocutor. This method gives the impression that the products offered are high in demand.

Copyright@2019, Dwi Novitasari, Budinuryanta Yohanes, Suhartono This is an open access article under the CC-BY-3.0 license
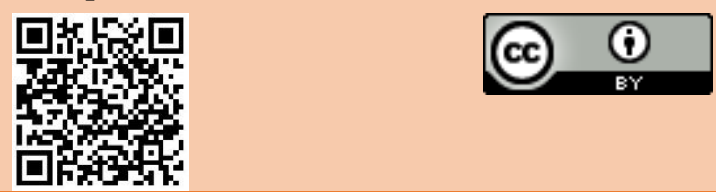

\section{PENDAHULUAN}

Istilah persuasi merupakan cara halus yang dilakukan penutur, dapat disebut bujukan, untuk meyakinkan lawan tuturnya agar melakukan apa yang dikehendaki penutur. Sebagian orang berpendapat bahwa memengaruhi orang lain merupakan hal yang sulit. Dalam hal ini persuasi merupakan salah satu strategi dalam bertutur agar dapat menguasai percakapan. Bahasa-bahasa persuasif banyak terdapat pada sebuah video tutorial. Bahasa tersebut diucapkan oleh naravlog dalam video. Naravlog menuturkan bahasa persuasif untuk menjadikan sebuah videonya terkesan menarik. Dalam hal ini, naravlog sebagai pemberi info tentang suatu hal, perlu 
melakukan rayuan bahkan bujukan kepada penonton agar tertarik dengan informasi yang disampaikan.

Naravlog yang telah disinggung sebelumnya, dapat diartikan sebagai penutur bahasa dalam video. Vlog berasal dari kata 'video' dan 'blog', merupakan sarana untuk meluapkan ekspresi, menyalurkan hobi, serta ladang mencari uang untuk penggunanya. Vlog merupakan video dokumentasi jurnalistik yang ada dalam laman. Vlog berisi pikiran, hidup, opini, argumentasi, serta ajakan. Dengan berbagai tema, naravlog dapat berekspresi sesuai dengan apa yang ingin ditunjukkan. Setelah merekam, naravlog mengunggah sejumlah video yang menurut mereka menarik sesuai dengan tema-tema yang sedang viral. Dengan gaya tertentu, naravlog menunjukkan kemahirannya berbicara di depan kamera video, kemudian diunggah di akun youtube-nya.

Tuturan persuasif dalam video blog kecantikan yang dikupas dengan kajian pragmastilistika dapat direntangkan sebagai upaya intepretasi penutur dalam proses menarik hati lawan tuturnya pada sebuah bahasan tertentu. Dalam hal ini setiap naravlog kecantikan memiliki tindak persuasif, gaya persuasif, dan teknik persuasif tersendiri saat menampilkan videonya. Di samping cara bertutur, konteks juga berpengaruh dalam upaya mengintepretasi tujuan penutur. Naravlog bertutur dengan beberapa gaya bahasa yang memiliki ciri khas tersendiri melalui gaya tuturan. Masalah tersebut dapat direntangkan pada bentuk tindak persuasif, gaya persuasif serta teknik-teknik persuasi.

Bentuk persuasif dalam video blog kecantikan terbagi atas enam hal yang menyatakan makna secara pragmatik, yakni konsistensi, hubungan timbal balik, otoritas, pembuktian sosial, rasa suka, dan kelangkaan. Dengan demikian dalam video blog kecantikan, naravlog menjadi penutur yang mengajak penonton untuk melakukan apa yang dimaksud. Pada saat memersuasi lawan tuturnya, naravlog kecantikan memakai gaya bertutur sesuai dengan dirinya. Hal tersebut menjadi ciri khas dari setiap naravlog. Permainan bahasa ditampilkan dalam video blog oleh para naravlog.

Ada beberapa penelitian terdahulu yang relevan dengan penelitian ini, yang saling bersentuhan dari segi fokus penelitian maupun kajiannya yang secara singkat akan dipaparkan guna mendapatkan perbedaan karakteristik penelitian ini dengan penelitian sebelumnya. Pertama, penelitian yang dilakukan oleh Taufik (2013) berjudul Wujud-wujud Tuturan Persuasif dalam Kampanye Pemilihan Bupati dan Wakil Bupati Pasuruan Tahun 2008 Ditinjau dari Perspektif Tindak Tutur. Penelitian kualitatif ini dilakukan dengan tujuan mengungkap dan menjelaskan bentuk, strategi dan nilai-nilai sosial budaya setiap tuturan yang terkait dengan perilaku paslon dalam kegiatan kampanye. Dalam penelitian ini ditemukan strategi tuturan persuasif dalam tuturan langsung, tak langsung, serta nilai-nilai budaya dalam tuturan persuasif. Penelitian ini juga memaparkan bahwa Tuturan persuasif dalam penelitian yang dilakukannya pun di luar tindak tutur direktif.

Kedua, penelitian yang berjudul Interpretasi Tuturan Persuasif Iklan untuk Menungkatkan Ekonomi Kreatif pada tahun 2017 yang dilakukan oleh (Fatimah, Sulistyo, \& Shaddhono, 2017), dengan fokus penelitian tentang intepretasi tuturan persuasif dalam iklan. Penelitian ini mengaitkan bentuk tuturan persuasif dalam iklan sebagai wadah untuk memasarkan sebuah produk agar tersampaikan ke segala lapisan masyarakat yang notabenenya memiliki perbedaan tingkat perekonomian. Di dalamnya dipaparkan bagaimana fungsi persuasif yang mampu menggerakkan kreativitas masyarakat bahasa untuk ladang uang melalui berbagai suguhan iklan yang dipromosikan. Oleh karena itu, para pelaku dunia usaha yang ingin memasarkan produknya harus mampu menghasilkan ide-ide yang dapat menarik minat konsumen. Ide-ide yang menarik dapat tersalurkan melalui bahasa. Bahasa yang digunakan berupa tuturan persuasif. Tuturan persuasif berfungsi memengaruhi konsumen untuk melihat lebih mendalam 
mengenai produk yang ditawarkan. Hal ini dapat meningkatkan laba pelaku industri apabila tuturan persuasif mampu membuat konsumen tertarik dan membeli produk.

Ketiga, penelitian yang dilakukan oleh Asmaniah (2015) dengan judul Naskah Drama Rajapati Karangan Ahmad Bakri (Kajian Struktural dan Pragmastilistik). Dalam penelitian ini, ditemukan sebuah kajian pragmastilistik yang terdiri dari dua unsur kajian yaitu pembagian pragmatik dan pembagian stilistik yaitu unsur-unsur majas dalam kalimat. Unsur-unsur pragmatik dan stilistik dalam naskah drama tersebut digabung dan ditentukan sebanyak sembilan belas pola verba performatif berdasarkan majas. Pragmastilistika dalam penelitian ini terdiri atas beberapa unsur yang masing-masing dikelompokkan ke dalam kajian pragmatik dan stilistika. Untuk pragmatik terbagi menjadi tujuh bagian, sedangkan stilistika terdiri atas dua unsur majas yaitu retoris dan kiasan. Kedua unsur tersebut digabungkan menjadi unsur pragmastilistika yang memiliki sembilan belas pola berdasarkan majas.

Ketiga penelitian tersebut relevan dengan penelitian ini dari segi fokus dan modus penelitian. Kajian dalam penelitian ini menggunakan kajian pragmastilistika dalam menemukan tindak tutur persuasif, gaya bahasa persuasif, serta teknik dalam memersuasi lawan tutur. Dua penelitian lainnya penggunakan kajian pragmatik saja. Penelitian ketiga, yaitu penelitian Asmaniah, menggunakan kajian pragmastilistika untuk menemukan struktur dan gaya pada teks sastra yang tidak melibatkan konteks sebagai hakikat dari pragmastilistika.

Perbedaan berikutnya terletak pada lingual korpus data penelitian. Korpus data dalam penelitian ini berupa kata, frasa, klausa, dan kalimat, sedangkan dalam penelitian lainnya, antara lain penelitian pertama menggunakan korpus data ujaran segmental kata, frasa, klausa, dan kalimat. Kemudian penelitian kedua hampir sama yaitu menggunakan korpus data ujaran segmental pada iklan berupa kata, frasa, klausa, dan kalimat. Penelitian yang ketiga menggunakan korpus data pada teks sastra yang berupa segmental kata, frasa, klausa, dan kalimat.

Dari korpus data dalam beberapa penelitian dapat dijadikan dasar penelitian linguistik sebab ketiganya bersifat natural. Melalui perbedaan tersebut, secara prosedural penelitian ini mendalami bentuk tindak persuasif menggunakan gaya bahasa dalam bertutur dan teknik-teknik persuasif dalam video blog kecantikan. Penelitian ini menggunakan kajian pragmastilistika karena dalam pembagian fokus, terdapat kesamaan antarnaravlog dalam memersuasi penonton meskipun dari wacana yang berbeda. Dengan demikian, penggunaan teknik untuk memersuasi penonton bermacam-macam. Dengan pragmastilistika, peneliti menguraikan berbagai macam tuturan naravlog ditinjau dari bentuk, gaya dan teknik memersuasi penonton dalam video blog kecantikan.

Persuasi merupakan cara untuk meyakinkan seseorang yang disertai dengan bujuk rayu agar seseorang melaksanakan apa yang dikehendaki oleh penutur. Menurut Keraf (2010) persuasi adalah seni verbal yang dilakukan penutur untuk meyakinkan lawan tutur agar lawan tutur melakukan apa yang dikehendaki oleh penutur pada saat ini atau saat yang lain. Persuasi tidak dibenarkan jika berbentuk paksaan maupun kekerasan. Oleh karena itu, tindakan persuasif menggunakan upaya tertentu untuk menarik lawan tutur untuk melakukan apa yang penutur inginkan.

Menurut Keraf (2010) persuasi tidak mengambil bentuk paksaan maupun kekerasan terhadap lawan tuturnya. Oleh karenanya, hal tersebut memerlukan upaya tertentu untuk dapat merangsang orang lain untuk mengambil keputusan seperti yang diinginkannya. Upaya yang dilakukan dapat berupa bukti-bukti, walaupun tidak setegas dalam sebuah argumentasi. Argumentasi menunjukkan hal yang bersifat fakta, dibuktikan dengan hal lain sebagai pendukung keterangan. Sedangkan persuasi, hanya membutuhkan dukungan berupa kalimat yang belum tentu dapat dibuktikan kebenarannya. 
Tuturan persuasif naravlog kecantikan menggunakan nada tinggi, serta ekspresi yang dalam, sehingga menimbulkan kesan pemaksaan terhadap penonton. Tuturan seorang naravlog yang bertujuan mengajak tersebut keluar dengan bentuk kalimat paksaan, meskipun diselingi dengan gurauan yang berciri khas. Kembali pada pengertian dari persuasi itu sendiri dilakukan dengan tanpa paksaan, maka para naravlog tidak akan dapat memaksa penonton. Menurut Altikriti (2016) persuasi diuraikan dengan berbagai cara seperti memanipulasi, meyakinkan, memengaruhi, atau menggoda. Hal tersebut difokuskan agar pesan persuasif menjadi efektif antara sikap dan tindakan. Penutur berupaya mewujudkan tujuan dengan melakukan tindakantindakan tertentu hingga lawan tutur dapat terpengaruh. Hal tersebut menjadi tanda keberhasilan pesan persuasif.

Stilistika merupakan gaya bahasa yang digunakan seorang penutur yang memiliki dua variabel bentuk maupun penggunanya. Stilistika yang lebih mengedepankan gaya berbahasa merupakan kajian yang memetakan bahasa dalam kajian retoris dan makna kias. Menurut Sudjiman (1993) gaya bahasa adalah cara penutur untuk dapat menyampaikan pesan yang dimaksudkan kepada lawan tutur dengan bahasa sebagai media utama dalam penyampaian pesan tersebut. Berdasarkan pendapat tersebut dapat dilihat seorang naravlog kecantikan akan menggunakan gaya bahasa sebagai ciri khasnya, yang kerap diulang di setiap video unggahannya. Hal tersebut akan menjadi sebuah ciri khas bahasa setiap naravlog kecantikan.

Berdampingan dengan pendapat itu, Keraf (2010) memiliki pendapat lain tentang stilistika yang dibedakan menjadi dua bentuk berdasarkan struktur kalimat dan makna langsung dan tidak langsung berdasarkan tuturan tersebut. Dalam langsung maupun tak langsungnya, gaya bahasa dibedakan lagi menjadi dua hal yaitu gaya bahasa kiasan dan gaya bahasa retoris. Gaya bahasa kiasan merupakan penyimpangan makna yang lebih jauh dari makna sebenarnya, sedangkan gaya bahasa retoris hanya menyimpang dari kontruksi bahasa umum untuk mencapai pada efek tertentu (Fransori, 2017).

Pragmastilistika merupakan sebuah kajian interdisipliner dari stilistika dan pragmatik. Menurut Black (2011) stilistika menggunakan pragmatik untuk menafsirkan dunia makna yang relatif tidak stabil. Teori pragmastilistika merupakan gabungan dari dua disiplin ilmu, yaitu pragmatik dan stilistika. Pragmatik adalah cabang ilmu linguistik yang memperhatikan teks, koteks, dan konteks untuk menjadi sebuah tuturan. Sedangkan stilistika adalah salah satu cabang ilmu bahasa yang memperhatikan gaya bahasa yang khas dari seseorang untuk mengungkapkan jati diri. Jadi stilistika berhubungan langsung dengan ciri khas berbahasa yang dimiliki oleh seorang penutur bahasa (Murtafi, Nababan, \& Djatmika, 2017).

Black berpendapat bahwa pengungkapan gaya/style melalui pragmatik digunakan untuk menafsirkan dunia makna yang relatif tidak stabil. Sebagian besar penggunaan bahasa para naravlog kerap tidak stabil menyebabkan mereka bertutur dengan ciri khas mereka sendiri (Lamusu, 2010). Cara pengungkapan gaya bahasa pada seseorang meliputi setiap aspek bahasa, seperti kata-kata, nada, kiasan, bahkan susunan kalimat. Hal tersebut bersinggungan dengan sebuah pemahaman bahwa gaya bahasa adalah suatu perwujudan bahasa yang digunakan seorang penutur atau penulis dalam menyampaikan gagasan serta gambaran sehingga timbul sebuah efek bagi lawan tutur.

Gaya berbicara seorang naravlog menitikberatkan pada proses pengayaan tuturan baik tuturan yang jelas kaidah kebahasannya maupun tidak. Yang terpenting menurut data, pengunjung akun youtube miliknya kian bertambah dari waktu ke waktu. Menurut Black (2011), wacana sastra berbeda dari percakapan keseharian dan dari wacana tulis tertentu karena semua karya yang diterbitkan tentunya sudah dikomposisikan dan direvisi secara seksama.

Tindak persuasif adalah bentuk tuturan berdasarkan prinsip tindak tutur direktif. Tindak persuasif memiliki fungsi untuk memerintah, menyuruh, atau meminta lawan tutur untuk melakukan tindakan sesuai apa yang diinginkan penutur (Yanto, Rusminto, \& Tarmini, 2013). 
Menurut Taufik (2013) tindak persuasif merupakan tindakan manipulatif yang memberikan persepsi pilihan kepada penerimanya. Tindakan persuasif tersebut, diharapkan mampu menarik perhatian lawan tutur.

Pendapat lain dikemukakan oleh Nirmala (2017) bahwa bentuk komunikasi persuasi yang tepat berdasarkan tujuan baiknya menggunakan metode persuasi tidak langsung. Untuk mencapai tujuannya, penutur tidak langsung memerintah akan tetapi menggunakan kalimat halus yang berbentuk ajakan, imbauan, dan lain-lain. Hal tersebut dilakukan penutur agar target menjadi percaya diri dan tidak merasa terbebani dengan perintah yang bersifat implisit (Arifin \& Agustina, 2017). Kalimat tersebut diucapkan dengan mengharapkan tindakan lawan tutur sebagai wujud dari keinginan penutur. Dalam video blog kecantikan, naravlog menuturkan ajakannya mulai dari pengaplikasian produk, cara penggunaan produk, bahkan mempersilakan penonton untuk mencoba membuktikan hasil penilaiannya terhadap produk kecantikan.

Dari beberapa pendapat dapat disimpulkan bahwa tindak persuasif memiliki bentuk tersendiri dalam ujaran (Azzam \& Rahyono, 2018). Hal tersebut menjadi pembeda dengan tindak imperatif secara langsung, meskipun di dalam ujaran persuasif secara implisit mengandung kalimat imperatif. Menurut Taufik (2013) bentuk tindak persuasif terdiri dari empat prinsip. Prinsip kekuatan digunakan oleh para penutur untuk memengaruhi seseorang agar melakukan apa yang diinginkan penutur. Berikut perincian bentuk tindak persuasif yang terdiri dari (a) konsistensi, (b) otoritas, dan (c) pembuktian sosial.

a. Konsistensi

Konsistensi merupakan ujaran penutur yang tidak bertentangan dengan keadaan sebenarnya. Sikap konsisten sangat penting karena sikap tersebut mengandung nilai kejujuran dan apa adanya. Konsistensi adalah kunci utama dalam meraih tujuan karena sikap konsisten dominan dalam mengarahkan perilaku manusia. Konsep tersebut sesuai prinsip kerja sama. Tindak persuasif dalam berkomunikasi memerlukan adanya konsistensi tuturan (Cahyadi \& Koswara, 2016). Hal tersebut diawali dengan kejujuran penutur dalam menginformasikan suatu hal. Dengan demikian, maksud dan tujuan penutur untuk lawan tutur akan terlaksana (Azzam \& Rahyono, 2018).

b. Otoritas

Fatimah et al. (2017) berpendapat bahwa otoritas adalah wewenang membuat aturan. Aturan tersebut dibuat untuk mendapatkan kepatuhan terhadap sasaran persuasi. Oleh karena itu, kepatuhan terhadap orang yang memiliki otoritas adalah dasar dalam prinsip memersuasi. Dalam video blog kecantikan, naravlog sebagai penutur tunggal memiliki kekuasaan bertutur tanpa adanya lawan tutur aktif. Naravlog kecantikan memiliki kekuasaan bertutur menyampaikan informasi produk make up pada penonton. Hal tersebut menjadikan daya tarik penonton untuk memerhatikan naravlog.

c. Pembuktian sosial

Pembuktian sosial adalah prinsip persuasif yang dilakukan dengan merekayasa hal yang tidak menarik menjadi menarik diminati banyak orang. Menurut Taufik (2013) pembuktian sosial adalah cara menimbulkan kesan yang dilakukan penutur kepada lawan tutur. Cara tersebut menimbulkan kesan bahwa produk yang ditawarkan banyak peminatnya. Hal ini dapat dibuktikan dengan banyaknya penilaian yang disebutkan oleh naravlog tentang produk yang dibahas dalam videonya. Cara-cara ini dapat mengecoh penonton untuk membeli produk yang dibahas dalam video kecantikan.

Manusia dapat bereaksi secara otomatis dengan bujukan (Ibrahim, Shiratuddin, \& Wong, 2013). Dengan tuturan persuasif penutur dapat mendominasi percakapan serta mengarahkan pandangan lawan tutur melalui beberapa teknik. Dalam video blog kecantikan, naravlog memersuasi penonton menggunakan beberapa teknik bertutur. Dari paparan tersebut dapat ditarik fokus permasalahan pada penelitian ini, yakni bagaimanakah bentuk persusif 
dalam video blog kecantikan? Penelitian ini bertujuan mendeskripsikan beberapa bentuk persuasif dalam video blog kecantikan.

\title{
METODE
}

Penelitian ini menggunakan pendekatan kualitatif. Pendekatan kualitatif menekankan pada deskripsi proses pengayaan pada unsur yang diubah untuk disesuaikan dengan bentuk tuturan penutur asli. Penelitian ini menekankan pada makna dan penalaran yang melibatkan konteks stilistika dan pragmatis. Berdasarkan fokus penelitian, data dalam penelitian ini adalah data lisan dan bersifat verbal.

Berdasarkan fokus penelitian, data dalam penelitian ini adalah data lisan dan bersifat verbal. Data verbal dalam penelitian ini berupa video tutorial dan review dari empat naravlog kecantikan antara lain SS, IV, dan FB sebanyak tiga konteks video dari masing-masing naravlog. Data tersebut ditentukan karena sesuai dengan fokus permasalahan yaitu bentuk tindak persuasif, gaya bahasa persuasif, dan teknik persuasi. Data tersebut diperoleh dari akun youtube yang menyajikan data dalam bentuk audiovisual.

Sumber data dalam penelitian ini adalah tuturan persuasif dalam video blog kecantikan yang diambil rekaman video blog yang terbagi atas empat orang naravlog. Karena yang dibutuhkan dalam fokus penelitian ini adalah audio dan visual, peneliti menyesuaikan dengan menyajikan data dalam bentuk audiovisual. Tuturan persuasif dalam video blog kecantikan adalah bentuk tindakan dengan menggunakan gaya bertutur dengan teknik tertentu di hadapan lawan tutur. Jadi, istilah tuturan persuasif dalam video blog kecantikan tidak hanya merujuk pada konteks video saja, akan tetapi juga merujuk pada tuturan dan gaya bertutur yang khas dari naravlog.

Dalam pengaplikasian teknik penyediaan data, peneliti merupakan instrumen utama pengumpul data. Adapun instrumen lain yang digunakan dalam penelitian ini adalah alat simak dan tulis yang membantu operasionalisasi instrumen utama dalam kegiatan penyediaan data. Penyediaan data bersifat natural. Oleh karena itu, dalam proses penyediaan data diperlukan instrumen penunjang. Instrumen yang dimaksud adalah kartu data, lembar klasifikasi data tiap rumusan masalah yang disertai dengan konteks dan kode data.

\section{TABEL ANALISIS TUTURAN PERSUASIF DALAM VIDEO BLOG KECANTIKAN}

\section{Keterangan:}

Data : 01 - dan seterusnya

BP: Bentuk Persuasif

Ks: Konsistensi

Ot: Otoritas

Pb: Pembuktian

\author{
WI: Wardah Instaperfect \\ Px: Pixy \\ Pb: Purbasari
}

\begin{tabular}{lllll}
\hline \multirow{2}{*}{ No } & \multirow{2}{*}{ Data } & Tuturan & \multicolumn{2}{c}{ Bentuk Tindak Persuasif } \\
\cline { 3 - 3 } & Persuasif & \multirow{2}{*}{ Kode } \\
\cline { 3 - 4 } & & Konsistensi & Otoritas & Pembuktian \\
\end{tabular}

Penelitian ini adalah penelitian dengan pendekatan kulitatif yang pada analisis datanya bersifat induktif dan berkelanjutan. Oleh karena itu, penelitian ini menekankan pada pendeskripsian yang bersifat objektif dengan menggunakan analisis pragmatik fungsional. 
Berdasar metode yang telah dipilih, diharapkan penelitian ini masuk dalam kategori penelitian ilmiah. Keilmiahan penelitian ini dapat ditentukan dengan menunjukkan kedalaman konsep berpikir secara ilmiah dan objektif dalam meliput tuturan persuasif dalam video blog kecantikan.

\section{HASIL DAN PEMBAHASAN}

Bab ini menyajikan deskripsi hasil temuan penelitian tentang tuturan persuasif dalam video blog kecantikan yang dianalisis menggunakan metode analisis pragmatik fungsional. Jadi, dalam bab ini mengembangkan deskripsi konteks yang unsur-unsurnya dipertukarkan secara berulang, kemudian diklasifikasikan sesuai prosedur. Hasil prosedur tersebut dipertukarkan dalam konteks serupa dan diidentifikasi menurut topik. . Analisis difokuskan pada bentuk tuturan persuasif, gaya bahasa persuasif, dan teknik persuasif naravlog dalam beberapa video blog kecantikan yang telah ditranskripsi dalam korpus data.

\section{HASIL}

Tuturan persuasif dalam video blog kecantikan adalah bentuk tuturan naravlog menggunakan gaya bahasa dengan teknik-teknik memersuasi untuk memenuhi tujuan. Tuturan persuasif digunakan naravlog untuk mengajak, bahkan membujuk penonton melalui berbagai cara tanpa adanya kekerasan maupun paksaan, akan tetapi menggunakan upaya keras agar tujuan terpenuhi (Fatimah et al., 2017). Naravlog memersuasi penonton dengan cara bertutur menggunakan gaya yang bermakna langsung maupun tak langsung guna memerdaya penonton agar melakukan apa yang dituturkan. Berikut disajikan tabel 1 pengolahan data.

Tabel 1

Tabel Pengolahan Data Bentuk Persuasif

\begin{tabular}{|c|c|c|c|c|c|c|}
\hline \multirow[t]{2}{*}{ No } & \multirow[t]{2}{*}{ Data } & \multirow{2}{*}{$\begin{array}{l}\text { Tuturan } \\
\text { Persuasif }\end{array}$} & \multicolumn{3}{|c|}{ Bentuk Tindak Persuasif } & \multirow[t]{2}{*}{ Kode } \\
\hline & & & Konsistensi & Otoritas & Pembuktian & \\
\hline 1 & $\begin{array}{l}\text { Hello wecome } \\
\text { back to my } \\
\text { chanel. Maaf ya } \\
\text { ini kacanya } \\
\text { kayaknya } \\
\text { ganggu banget, } \\
\text { tapi aku perlu } \\
\text { sekali kaca ini } \\
\text { di sini. Jadi, } \\
\text { ampun. Ehm... } \\
\text { seperti } \\
\text { judulnya, kali } \\
\text { ini gue mau } \\
\text { melanjutkan } \\
\text { review } \\
\text { produknya } \\
\text { wardah yang } \\
\text { instaperfect } \\
\text { lagi, karena ini } \\
\text { kayak mereka } \\
\text { ngeluncurin } \\
\text { produk baru } \\
\text { lagi, kayak } \\
\text { semacam } \\
\text { gelombang } \\
\text { kedua gitu. Dulu }\end{array}$ & $\begin{array}{l}\text { ".... } \\
\text { Maaf ya ini } \\
\text { kacanya } \\
\text { kayaknya } \\
\text { ganggu } \\
\text { banget, tapi } \\
\text { aku perlu } \\
\text { sekali kaca } \\
\text { ini di sini. } \\
\text {..." }\end{array}$ & $\begin{array}{l}\text { Mengakui } \\
\text { bahwa } \\
\text { penutur } \\
\text { membutuhk } \\
\text { an kaca } \\
\text { sebagai } \\
\text { sarana } \\
\text { merias } \\
\text { wajah }\end{array}$ & & & WI. BP. Ks. 01 \\
\hline
\end{tabular}


gua sudah

pernah bikin

videonya yang

seri pertama,

bukan seri

pertama, produk

pertama yang

mereka

luncurkan.

\begin{tabular}{|c|c|c|c|c|c|}
\hline 2 & 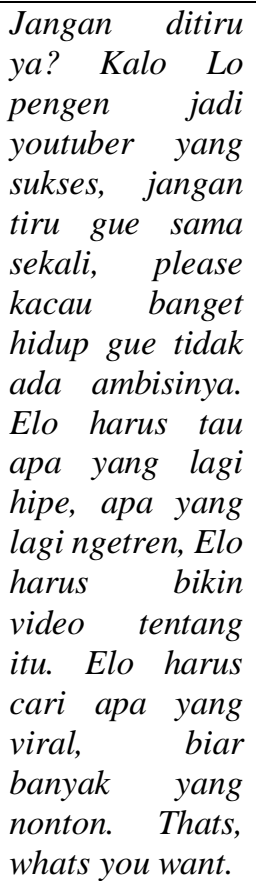 & $\begin{array}{c}\text { “Jangan } \\
\text { ditiru ya? } \\
\text { Kalo Lo } \\
\text { pengen jadi } \\
\text { youtuber } \\
\text { yang sukses, } \\
\text { jangan tiru } \\
\text { gue sama } \\
\text { sekali, } \\
\text { please } \\
\text { kacau } \\
\text { banget } \\
\text { hidup gue } \\
\text { tidak ada } \\
\text { ambisinya. } \\
\text {...” }\end{array}$ & $\begin{array}{c}\text { Memerinta } \\
\mathrm{h} \\
\text { penonton } \\
\text { untuk } \\
\text { tidak } \\
\text { meniru } \\
\text { perlakuan } \\
\text { nya }\end{array}$ & & WI. BP. Ot. 03 \\
\hline 3 & 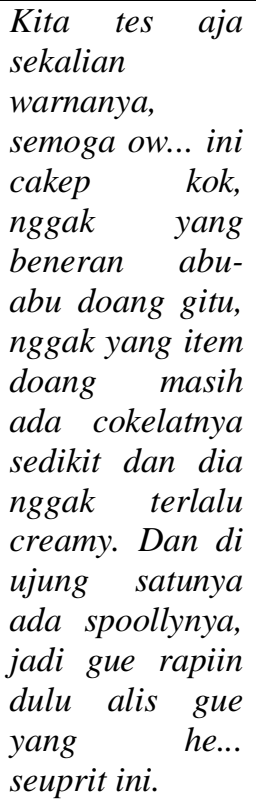 & $\begin{array}{c}\text { "Kita tes } \\
\text { aja sekalian } \\
\text { warnanya, } \\
\text { semoga ow... } \\
\text { ini cakep } \\
\text { kok, nggak } \\
\text { yang } \\
\text { beneran } \\
\text { abu-abu } \\
\text { doang gitu, } \\
\text { nggak yang } \\
\text { item doang } \\
\text { masih ada } \\
\text { cokelatnya } \\
\text { sedikit dan } \\
\text { dia nggak } \\
\text { terlalu } \\
\text { creamy...." }\end{array}$ & & $\begin{array}{c}\text { Membuktikan } \\
\text { ketajaman } \\
\text { warna dari } \\
\text { pensil alis } \\
\text { yang dinilai } \\
\text { baik, } \\
\text { meskipun } \\
\text { berwarna abu- } \\
\text { abu masih } \\
\text { terlihat } \\
\text { menyatu } \\
\text { dengan warna } \\
\text { bulu alis yang } \\
\text { hitam. }\end{array}$ & WI. BP. Pb. 04 \\
\hline
\end{tabular}




\section{PEMBAHASAN}

Bentuk tuturan persuasif adalah bentuk tuturan berdasarkan prinsip tindak tutur direktif. Bentuk tuturan persuasif memiliki fungsi untuk memerintah, menyuruh, atau meminta lawan tutur untuk melakukan tindakan sesuai apa yang diinginkan penutur. Adapun kategori bentuk tuturan persuasif, yakni konsistensi, otoritas, dan pembuktian.

\section{Konsistensi}

Konsistensi adalah ujaran penutur yang tidak bertentangan dengan keadaan sebenarnya. Bentuk tuturan konsistensi terlihat pada saat penutur menunjukkan keadaan sebenarnya tentang sesuatu. Konsistensi adalah sarana utama memperoleh tujuan bertutur. Dalam memersuasi, selain menunjukkan kelebihan, penutur pun harus menunjukkan kekurangan yang konsisten agar tuturan tidak terkesan membujuk. Menurut Altikriti (2016) tindak persuasif dalam berkomunikasi memerlukan adanya konsistensi tuturan. Hal tersebut diawali dengan kejujuran penutur dalam menginformasikan suatu hal. Dengan demikian, maksud dan tujuan penutur untuk lawan tutur akan terlaksana. Berikut contoh bentuk tuturan konsistensi.

1) "Hello, wecome back to my chanel. Maaf ya ini kacanya kayaknya ganggu banget, tapi aku perlu sekali kaca ini di sini. Jadi, ampun. Ehm... seperti judulnya, kali ini gue mau melanjutkan review produknya wardah yang instaperfect lagi, karena ini kayak mereka ngeluncurin produk baru lagi, kayak semacam gelombang kedua gitu. Dulu gua sudah pernah bikin videonya yang seri pertama, bukan seri pertama, produk pertama yang mereka luncurkan."

(WI. BP. Ks. 01)

Data 1 merupakan tuturan SS, naravlog kecantikan yang memiliki pengikut lebih dari satu juta lima ratus. SS adalah naravlog kecantikan lulusan Universitas Indonesia jurusan Manajemen. Dalam video, penutur memiliki karakter bertutur yang bebas, lucu dan menggunakan bahasa aneh. Akan tetapi, tuturan tersebut terkesan jujur dan apa adanya. Hal tersebut dapat dibuktikan dalam semua video penutur yang cenderung berlebihan dalam menganalogikan sesuatu. Tuturan tersebut menjadi ciri khas bahasa yang dituturkan oleh SS. Contoh ditemui pada awal video selalu terdapat kalimat" "Hello, welcome back to my channel", diucapkan dengan nada dan akspresi wajah yang sama. Penutur memberikan informasi kepada penonton melalui video. Respon lawan tuturnya dapat dilihat dari semua komentar pada video tersebut.

Dalam data ini penutur memberikan informasi lengkap tentang produk Wardah Instaperfect. Dalam bertutur, SS menambah gerakan tangan untuk menyelaraskan tuturan dengan ekspresi. Pada awal tuturan, penutur mengucapkan sapaan kepada penonton, kemudian menuturkan tentang benda berupa kaca telah mengganggu gambar kamera. Tuturan tersebut berbentuk konsistensi. Penutur berbicara tentang kaca yang dimilikinya terlihat dalam kamera, dan menyadari bahwa kaca tersebut mengganggu pandangan penonton. Akan tetapi, penutur tidak membuang kaca tersebut, sehingga penutur melanjutkan kalimatnya dengan meminta maaf jika kaca tersebut mengganggu.

Bentuk ujaran dalam data tersebut berproposisi pada kaca yang mengganggu pandangan. Jika diperhatikan, kaca tersebut tidak akan mengganggu pandangan penonton. Karena terdapat tuturan tentang kaca yang mengganggu, maka penonton akan melihat kaca yang sedikit terlihat dalam kamera. Hal tersebut merupakan tuturan persuasif yang dituturkan kepada penonton untuk memfokuskan pandangan pada kaca. Penutur berusaha mendeskripsikan hal yang tidak penting, akan tetapi pengucapannya dengan menggunakan gaya bahasa dan teknik tertentu mengakibatkan penonton memerhatikan penutur.

2) "Dan ini langsung aja, sebelumnya aku mau ngasih tau dulu. This is not a sponsor's video, aku belum di-endorse sama Wardah. Jadi aku beli sendiri, aku nyari nyari di Lazada, di Shopee, di 
Tokopedia ada. Jadi kalau kalian pengen nyari, bisa diklik aja. Nanti aku bakalan kasih tahu. Coba deh di descriptionbox aku kasih tau."

(WI. BP. Ks. 13)

Data 2 adalah tuturan FB, naravlog kecantikan yang memiliki lebih dari enam ratus ribu pengikut. FB menjadi naravlog kecantikan sejak 2015, dan mengisi konten youtube-nya dengan informasi-informasi seputar kecantikan. Dalam videonya, FB menggunakan gaya bahasa yang sederhana dan pilihan katanya merupakan bahasa sehari-hari. Akan tetapi, penutur memberikan penekanan khusus pada penilaian produk yanki menilai secara objektif. Hal tersebut bertujuan mendapatkan kepercayaan dari penonton. Ungkapan yang menunjukkan maksud penutur terdapat dalam informasi bahwa penutur membeli semua produk dengan uang sendiri, jadi tidak ada kesepakatan khusus dengan merek dagang tertentu sebagai sponsor video.

Dalam menginformasikan produk, penutur menggunakan media akun youtube yang ditujukan pada penonton maupun pengikut. Penutur menggunakan dan menjadi penutur tunggal. Lawan tuturnya adalah pengikut yang merespon tuturan tersebut melalui kolom komentar dalam akun youtube. Dalam data ini, penutur menggunakan bahasa sehari-hari dengan tindakan tutur berupa permainan mata. Permainan bahasa yang dituturkan menjadikan ciri khas tersendiri untuk penutur.

Data ini merupakan tuturan persuasif yang menunjukkan bentuk konsistensi. Penutur menjelaskan bahwa tidak ada sponsor dalam video tersebut. Oleh karena itu, penutur memersuasi penonton dengan menekankan informasi tersebut. Pada tuturan 'this is not sponsor video, aku belum diendorse sama Wardah. Jadi aku beli sendiri, aku nyari-nyari sendiri di Lazada, di Shopee, di Tokopedia ada. ...' menunjukkan informasi sebenarnya tentang penilaian yang akan dilakukan. Konsistensi pada data tersebut mengakui dengan jujur tentang video yang tidak disponsori oleh pihak manapun. Tuturan tersebut berpreposisi pada tuturan penilaian yang objektif. Dengan demikian, penonton mendapatkan informasi yang benar tentang produk tersebut. Baik penutur maupun penonton bersepakat penilaian tersebut objektif ketika pembelian produk menggunakan uang pribadi. Jika sponsor dari pemilik merek dagang kemungkinan penilaian tidak dilakukan dengan objektif.

3) Trus ukuran nya juga kayak membuat bangga ketika kamu memegangnya. Nah, Wardah Instaperfect itu kalau aku lihat dari segi tekstur, dia nggak terlalu matte, nggak terlalu dewy. Jadi kayak pas gitu. E, trus juga dek e tu apa ya lak ngarani? Terlalu cover juga nggak. Jadi kalau misalnya untuk sehari-hari tu bagus banget.

(WI. BP. Ks. 25)

Data 3 merupakan tuturan IV, naravlog yang berasal dari Kota Malang, yang pengikutnya mendekati angka 2,5 juta. IV merupakan naravlog kecantikan yang menggunakan bahasa khas Malang - Jawa dalam video di akun youtube-nya. Hal tersebut menjadikan daya tarik penonton, dibuktikan dengan penonton yang mencapai angka puluhan ribu dalam setiap videonya. Dalam video, penutur menggunakan nada.

Nada tinggi disertai dengan bahasa Malangan (Jawa). Hal tersebut dapat ditemukan di semua video kecantikan yang dibuat. Sikap penutur bebas mengemukakan pendapatnya pada produk kecantikan, dengan tujuan memersuasi penonton agar mempercayai apa yang diinformasikan. Hal tersebut dapat dilihat dari banyaknya komentar dalam kolom komentar di akun youtube-nya.

Dalam data tersebut, penutur menginformasikan tentang produk Wardah Instaperfect secara tekstur bersifat biasa-biasa saja. Secara bentuk, tuturan persuasif tersebut merupakan konsistensi. Tujuan penutur menginformasikan keadaan tersebut untuk menunjukkan kebenaran keadaan produk. Menurut penutur, produk tersebut memiliki sifat tertentu yang tidak 
berlebihan dan tidak ada unsur melebih-lebihkan. Penutur menguraikan pendapatnya dengan objektif tentang produk tersebut. Dalam penjelasannya, penutur menilai keadaan produk yang standar, tidak terlalu bagus dan tidak terlalu buruk. Penilaian produk yang dilakukan oleh penutur bertujuan agar penonton mendapatkan informasi tentang produk tersebut.

Untuk tetap berada pada konteks memersuasi penonton, penutur menambahkan alternatif untuk menyikapi bentuk konsistensi tersebut. Penutur menambahkan dengan kalimat, "Jadi kalau misalnya untuk sehari-hari tu bagus banget" pada akhir tuturannya. Jadi meskipun produk tersebut kurang berkualitas, masih ada alternatif untuk tetap memakai produk tersebut. Bentuk konsistensi yang dituturkan oleh penutur menunjukkan adanya keadaan yang sebenarnya tentang produk yang dinilai. Konsistensi pada data 3 terletak pada frasa 'tidak terlalu'. Karena frasa tersebut mewakili keadaan produk yang jika dideskripsikan dengan frasa 'standar', menjadi kurang menarik.

4) "Baiklah, menurut gua bedaknya, covered-nya nggak terlalu tinggi untuk ukuran sebuah compact powder. Masih lebih tinggi yang seri kemarin yang warna pink ini, dia jauh lebih nutup. Cuma kalau dibandingin sama cushion-nya tadi, harusnya nggak masalah. Karena cushionnya udah nutup banget coverednya, udah supeer tinggi. Jadi harus nya Elo nggak perlu setebel itu lagi bedaknya. Dan jangan lupa kalau primernya tadi tu udah ada efek ngratain warna kulitnya, biarpun sangat-sangat tipis coverednya, tapi udah dapet kok efek nya. Tapi jangan salah paham yaa? Bedaknya nggak setipis itu juga, cuma untuk ukuran compact powder Indonesia yang pada umumnya sangat sangat tebel, dia tu masih termasuk ringan, termasuk agak tipis, mediumlah covered-nya"

$$
\text { (Px. BP. Ks. 35) }
$$

Data 4 adalah tuturan SS yang menunjukkan informasi kualitas produk, yang dituturkan dengan sederhana menggunakan bahasa biasa yang tidak berlebihan pengucapannya. Tuturan tersebut lebih datar pengucapannya dan menggunakan pembuktian dasar sebagai penguat maksud tuturan. Penutur memberikan informasi tentang ketebalan produk bedak yang tidak maksimal, bahkan membandingkannya dengan produk yang sama di seri yang sebelumnya. Tuturan tersebut bertujuan mengajak penonton untuk memperhatikan bahwa apa yang dituturkan adalah pendapat yang benar. Penutur memaparkan langsung dengan menunjukkan produk di depan layar video.

Bentuk konsistensi pada tuturan tersebut adalah kualitas produk bedak. Penutur mendeskripsikan tentang kualitas produk bedak yang memiliki ketebalan rendah. Penutur secara objektif mendeskripsikan penilaiannya untuk produk bedak yang dimaksud. Dijelaskan juga tentang mayoritas produk bedak di Indonesia kebanyakan bertekstur tebal, sehingga ada penilaian yang bermakna kurang sempurna untuk produk tersebut. Bentuk konsistensi dalam data 35 bertujuan untuk menunjukkan sedikit kekurangan dari produk yang dipakai.

Akan tetapi, penutur menambahkan keterangan tentang ketebalan produk tersebut jika bergabung dengan produk lain akan terlihat baik. Hal tersebut merupakan cara yang dilakukan penutur untuk memersuasi penonton secara halus. Meskipun kualitas produk tidak maksimal dengan apa yang diklaimkan, ada pendapat dari penutur untuk menggabungkan dua produk lain di seri yang sama. Tuturan tersebut merupakan persuasi yang ditujukan untuk mengajak penonton melakukan hal yang sama seperti dilakukan penutur.

Konsistensi pada data 35 ini berbeda dengan data sebelumnya. Hal yang membedakan konsistensi tersebut adalah ada pertimbangan lain sebagai pilihan untuk penonton. Penutur menambahkan alternatif lain sebagai penutup kekuarangan produk. Hal tersebut terdapat dalam tuturan, "... Karena cushionnya udah nutup banget coverednya, udah supeer tinggi. Jadi harus nya Elo nggak perlu setebel itu lagi bedaknya. Dan jangan lupa kalau primernya tadi tu udah ada efek ngratain warna kulitnya, biarpun sangat-sangat tipis coverednya, tapi udah dapet kok efek nya. Tapi jangan salah paham yaa? Bedaknya nggak setipis itu juga, cuma untuk ukuran 
compact powder Indonesia yang pada umumnya sangat sangat tebel, dia tu masih termasuk ringan, termasuk agak tipis, mediumlah covered-nya". Jadi meskipun penutur menyebutkan kekurangan produk sesuai dengan konsistensinya, penutur memberikan pilihan lain yang dapat digunakan untuk mengatasi hal tersebut.

\section{Otoritas}

Otoritas adalah prinsip untuk memengaruhi lawan tutur agar melakukan tindakan dengan memanfaatkan kekuasaan. Bentuk otoritas penutur berupa wewenang membuat aturan. Aturan tersebut dibuat untuk mendapatkan kepatuhan terhadap sasaran persuasi. Oleh karena itu, kepatuhan terhadap orang yang memiliki otoritas adalah dasar dalam prinsip memersuasi. Fatimah et al. (2017) berpendapat bahwa otoritas adalah wewenang membuat aturan. Aturan tersebut dibuat untuk mendapatkan kepatuhan terhadap sasaran persuasi. Oleh karena itu, kepatuhan terhadap orang yang memiliki otoritas adalah dasar dalam prinsip memersuasi.

Naravlog sebagai penutur tunggal memiliki kekuasaan bertutur tanpa adanya lawan tutur aktif. Naravlog kecantikan memiliki kekuasaan bertutur menyampaikan informasi produk make up pada penonton. Hal tersebut menjadikan daya tarik penonton untuk memerhatikan naravlog. Berikut data bentuk tindak otoritas penutur sebagai pemberi informasi.

5) Jangan ditiru ya? Kalo Lo pengen jadi youtuber yang sukses, jangan tiru gue sama sekali, please kacau banget hidup gue tidak ada ambisinya. Elo harus tau apa yang lagi hipe, apa yang lagi ngetren, Elo harus bikin video tentang itu. Elo harus cari apa yang viral, biar banyak yang nonton. Thats, what's you want.

\section{WI. BP. Ot. 03}

Data 5 adalah tuturan SS yang merujuk pada informasi tentang kredibilitas naravlog. Penutur memberikan pesan dan arahan kepada penonton untuk mengikuti apa yang diperintahkan. Tuturan tersebut bertujuan memersuasi penonton untuk memerhatikan penutur. Ditinjau dari maknanya, penutur melarang penonton menirukan apa yang dilakukannya. Akan tetapi, jika dilihat maksud penutur, maka dapat diketahui bahwa penutur hanya merendahkan diri saja, tidak bertutur sebenarnya.

Pesan yang disampaikan penutur kepada penonton memiliki tujuan memberikan informasi serta perintah untuk tidak menirukan apa yang dikerjakannya. Penutur menganggap dirinya bukan naravlog kecantikan yang baik, ditambah dengan nada tuturan yang menegaskan bahwa penutur memang tidak layak ditiru. Maksud tuturan tersebut adalah memersuasi penonton dengan bentuk otoritas. Bentuk otoritas dalam tuturan terletak pada larangan untuk meniru apa yang penutur lakukan. Otoritas dalam data tersebut berada pada tuturan imperatif. Karena penutur mempunyai wewenang dan kekuasaan, sehingga memerintah penonton dengan leluasa.

6) Jadi harganya tuh lebih di atas prodak prodak yang biasanya dijual di Wardah. Namaya itu adalah Wardah Instaperfect. Tapi menurut aku meskipun Wardah ini mengeluarkan yang namanya si premium prodak, harganya pun juga masih terjangkau banget atau afordible lah istilahnya.

(BP. WI. Ot. 12)

Data 6 adalah tuturan dari FB, naravlog kecantikan yang memiliki karakter sederhana dalam bertutur. Bahasa yang dituturkan pun tidak diberi tekanan berlebihan. Penutur memberikan informasi dalam perspektifnya tentang produk Wardah yang harganya murah. Latar belakang penutur adalah mahasiswa S2, yang memiliki latar belakang keluarga mampu. Oleh karena itu, penutur menganggap harga produk yang dimaksud dalam kategori murah. Tujuan penutur menginformasikan penonton tentang harga produk Wardah Instaperfect untuk memersuasi penonton agar mencoba produk tersebut. 
Data 12 menunjukkan otoritas penutur memberi penilaian harga pada produk. Bentuk otoritas tersebut digunakan untuk memersuasi penonton agar memercayai bahwa produk Wardah Instaperfect sangat murah. Meskipun demikian apa yang dituturkan penutur bukan kebenaran, hanya proposisi yang bisa dinegasi oleh lawan tutur atau penonton. Penutur memberi pendapat berdasar subjektivitas diri. Karena memiliki otoritas sebagai penutur tunggal dan didasari oleh ragam keterangan yang menunjukkan bahwa penutur memiliki produk yang lebih mahal dari produk tersebut, maka penutur menganggap bahwa harga Wardah Instapercfect tidak semahal produk lainnya.

\section{Pembuktian}

Pembuktian merupakan prinsip persuasif yang dilakukan penutur dengan merekayasa hal yang tidak menarik menjadi menarik diminati banyak orang. Pembuktian adalah cara menimbulkan kesan yang dilakukan penutur kepada lawan tutur. Menurut Taufik (2013) pembuktian sosial adalah cara menimbulkan kesan yang dilakukan penutur kepada lawan tutur. Cara tersebut menimbulkan kesan bahwa produk yang ditawarkan banyak peminatnya. Hal ini dapat dibuktikan dengan banyaknya penilaian yang disebutkan oleh naravlog tentang produk yang dibahas dalam videonya. Cara-cara ini dapat memersuasi penonton untuk membeli produk yang dibahas dalam video kecantikan. Berikut merupakan data bentuk tindak persuasif pembuktian.

7) Hay asalamuallaikum. Wr wb. Walcome back to my channel, walcome back to Fatiya Biya's channel. Dan kali ini, ini adalah video yang paling banyak dirikues belakangan ini, beberapa bulan ini, karena baru aja produk Wardah mengeluarkan kayak premium produknya mereka.

WI. BP. Pb. 11

Data 7 adalah tuturan yang berisi bentuk pembuktian mengenai permintaan pembuatan video tutorial make up dan penilaian produk Pixy Make It Glow. Penutur menginformasikan pembuatan video ini berdasar pada banyaknya permintaan penonton yang menginginkan informasi produk tersebut. Penutur memersuasi penonton kembali dengan menginformasikan bahwa video tersebut dibuat karena banyaknya penonton yang memintanya. Dengan tuturan tersebut penonton mendapat informasi bahwa video tersebut dikehendaki banyak orang.

Bentuk pem buktiannya dapat dilihat dari jumlah penonton, penyuka, dan komentator di bawah video. Hal tersebut dapat dijadikan acuan bukti kebenaran penutur tentang pembuatan video penilaian dan tutorial produk kecantikan.

\section{SIMPULAN}

Tuturan persuasif merupakan bentuk tindak tutur yang digunakan oleh penutur sebagai cara untuk memersuasi lawan tutur. Bentuk tindak konsistensi dalam memersuasi penonton dapat dilakukan ketika ada hal yang menimbulkan proposisi. Bentuk otoritas terjadi ketika penutur sangat memahami topik. Sedangkan bentuk pembuktian terjadi karena penutur ingin membenarkan tuturannya, yang disertai dengan bukti-bukti.

\section{DAFTAR PUSTAKA}

Altikriti, S. (2016). Persuasive Speech Acts in Barack Obama's Inaugural Speeches (2009, 2013) and the Last State of the Union Address (2016). International Journal of Linguistics, 8(2), 47-66.

Arifin, J., \& Agustina, L. (2017). Bentuk Tindak Tutur Persuasi Perawat dan Pasien di Puskesmas Banua Lawas Kabupaten Tabalong. STILISTIKA, 2(2), 250-261.

Asmaniah, Z. (2015). Naskah Drama Rajapati Karangan Ahmad Bakri (Kajian Struktural dan Pragmastilistik). LOKABASA, 6(2), 219-226. 
Azzam, A., \& Rahyono, F. (2018). Strategi Persuasif Wacana Integrasi Sosial dalam Ungkapan Jawa di Instagram. Paper presented at the Proceeding INUSHARTS (International Young Scholars Symposium.

Black, E. (2011). Stilistika Pragmatis. Yogyakarta: Pustaka Pelajar.

Cahyadi, A. D., \& Koswara, D. (2016). Kajian Struktural, Stilistika, dan Etnopedagogi dalam Kumpulan Puisi (Sajak) Periode Tahun 2000-an. LOKABASA, 5(1), 1-11.

Fatimah, F. N., Sulistyo, E. T., \& Shaddhono, K. (2017). Interpretasi Tuturan Persuasif Iklan untuk Meningkatkan Ekonomi Kreatif Paper presented at the Proceedings Education and Language International Conference.

Fransori, A. (2017). Analisis Stilistika pada Puisi Kepada Peminta-Minta Karya Chairil Anwar. DEIKSIS, 9(01), 1-12.

Ibrahim, N., Shiratuddin, M. F., \& Wong, K. (2013). Persuasion Techniques for Tourism Website Design. Paper presented at the Proceedings of The International Conference on E- Technologies and Buiness on the Web (EBW2013).

Keraf, G. (2010). Argumentasi dan Narasi. Jakarta: Gramedia.

Lamusu, S. (2010). Telaah Stilistika Puisi-Puisi Rendra dan Taufik Ismail. Jurnal Inovasi, 7(2), 33-45.

Murtafi, A., Nababan, N., \& Djatmika, D. (2017). Analisis Terjemahan Gaya Bahasa Repetisi dalam Novel A Thousand Splendid Suns, Teknik dan Kualitasnya (Kajian Penerjemahan dengan Pendekatan Stilistika). PRASASTI: Journal of Linguistics, 2(1), $1-20$.

Nirmala, V. (2017). Tindak Tutur Ilokusi pada Iklan Komersial Sumatera Ekspres. Kandai, 11(2), 139-150.

Sudjiman, P. (1993). Bunga Rampai Stilistika. Jakarta: Grafiti.

Taufik, K. S. (2013). Wujud-wujud Tututran Persuasif dalam Kampanye Pemilihan Bupati dan Wakil Bupati Pasuruan Tahun 2008 Dintinjau dari Perspektif Tindak Tutur Prosodi Jurnal Ilmu Bahasa dan Sastra, 7(2), 1-11.

Yanto, J. A., Rusminto, N. E., \& Tarmini, W. (2013). Representasi Kekuasaan Pada Tindak Tutur Guru dalam Pembelajaran Bahasa Indonesia. J-SIMBOL (Bahasa, Sastra, dan Pembelajarannya), 1(2), 36-45. 